\title{
Experimental Organism Benign Mixed Mullerian Tumor
}

National Cancer Institute

\section{Source}

National Cancer Institute. Experimental Organism Benign Mixed Mullerian Tumor. NCI

Thesaurus. Code C126085.

A benign neoplasm arising from pluripotent mesodermal cells of the Mullerian ducts.

(INHAND) 